\title{
LATENTNA STRUKTURA PONAŠANJA U VIRTUELNIM DRUŠTVENIM ZAJEDNICAMA I NJEGOVE RELACIJE SA SOCIJALNOM ANKSIOZNOŠĆU
}

\section{Bojana Bodroža', Sandra Jovanović i Boris Popov}

Filozofski fakultet, Novi Sad

Virtuelne društvene zajednice (VDZ) predstavljaju Internet servise za komunikaciju i razvoj socijalnih mreža koje privlače sve veći broj korisnika. Teorija socijalne kompenzacije koja nastoji da objasni privlačnost ovog vida komunikacije, implicira da bi komunikacija putem VDZ mogla posebno biti interesantna socijalno anksioznim, introvertnim i povučenim osobama, koje bi kroz nju mogle da kompenzuju nedostatak realnih interpersonalnih veština.

Istraživanje je sprovedeno sa ciljem da se ispita i opiše latentna struktura ponašanja u VDZ, kao $i$ da se utvrde njegove relacije sa socijalnom anksioznošću. U cilju operacionalizacije ponašanja korisnika ovih servisa konstruisan je upitnik Social Networking Behavior (SNB) koji sadrži 73 stavke.

Analizom glavnih komponenti iz prostora upitnika SNB ekstrahovano je pet dimenzija virtuelnih ponašanja: 1) Socijalizacija putem VDZ, 2) Zavisnost od VDZ, 3) Kompenzatorno korišćenje VDZ, 4) Virtuelni self i 5) Negativan stav prema VDZ. Osim u slučaju Negativnog stava prema VDZ, postoji značajna interkorelacija izolovanih latentnih dimenzija. Regresionom analizom je utvrđeno da je socijalna anksioznost povezana samo sa dimenzijom Zavisnost od VDZ, dok postoji tendencija povezanosti i sa dimenzijom Kompenzatorno korišćenje VDZ.

Dobijeni rezultati, iako delom potkrepljuju rezultate nekih prethodnih istraživanja koja su pokazala da Internet komunikacijski servisi mogu imati terapeutsko dejstvo na osobe sa problemima u domenu socijalnog funkcio-

\footnotetext{
${ }^{1}$ E-mail: bojana.bodroza@gmail.com
} 
nisanja, ukazuju na potencijalni rizik prilikom eventualnog korišćenja datih servisa $u$ terapiji socijalne anksioznosti usled opasnosti pojave zavisnosti od njih.

Ključne reči: virtuelno ponašanje, virtuelne društvene zajednice, socijalna anksioznost, Internet

\section{Uvod}

Pojavom Interneta komunikacija je nesumnjivo dobila novu dimenziju. Istraživanja koja su bila usmerena na otkrivanje prirode promene koju je doneo Internet dala su kontradiktorne rezultate. Nalazi nekih istraživanja navode na zaključak o negativnom delovanju Interneta na mentalno zdravlje i socijalni život njegovih korisnika (Kraut et al., 1998, prema Gross, Juvonen i Gable, 2002; Nie i Erbring, 2000, prema Campell, Cumming i Hughes, 2006). Međutim, postoje istraživanja koja pokazuju da Internet ne uništava socijalnu mrežu njegovih korisnika, već da je učvšćuje i pomaže njenom održavanju (Gross et al., 2002), kao i da ne dovodi do smanjenja učestvovanja njegovih korisnika u realnom društvenom životu (Katz i Aspden, 1997, prema Antonijević, 1999). Ona ukazuju na to da Internet njegovi korisnici upotrebljavaju kao još jednu alatku u svom komunikacionom repertoaru i negiraju postojanje štetnih efekata korišćenja Interneta.

Među pitanjima koje je fenomen Interneta pokrenuo je i pitanje karakteristika njegovih korisnika. Jedno od dominantnih stanovišta o karakteristikama korisnika Interneta opisano je kroz teoriju socijalne kompenzacije (Jochen, Valkenburg i Schouten, 2005). Ona odražava gledište da je komunikacija preko Interneta privlačna socijalno anksioznim, povučenim, introvertnim osobama, koje kroz ovaj vid komunikacije kompenzuju probleme u socijalnom funkcionisanju. $\mathrm{Na}$ taj način, virtuelna komunikacija pruža mogućnost opisanim korisnicima da se ostvare na socijalnom planu. Carducci i Zimbardo (1995, prema Chak i Leung, 2004) su ustanovili da stidljive osobe preferiraju komunikaciju preko Interneta usled percepcije bolje kontrole nad situacijom. Kontrolisanjem informacija koje neko o nama dobija smanjuje se mogućnost negativne evaluacije, a samim tim i socijalna anksioznost. Anonimnost i mogućnost kreiranja novog identiteta takođe su se pokazali relevantnim činiocima privlačnosti virtuelne komunikacije socijalno anksioznim osobama (Young, 2000, prema Chak i Leung, 2004). Na taj način posledice eventualno neuspešne komunikacije su relativizovane, što je značajno za smanjenje socijalne anksioznosti. Nalazi nekih istraživanja sugerišu viđenje Interneta i virtuelne komunikacije kao sigurnog okruženja u kome socijalno anksiozne osobe imaju priliku da poboljšaju svoje socijalne veštine, odnosno njegovog mogućeg terapijskog dejstva na redukciju socijalne anksioznosti 20 
(Roberts, Smith i Pollock, 2000, prema Scealy, Phillips i Stevenson, 2002). Međutim, postoje i suprotna gledišta, koja podržavaju tezu da socijalno anksiozne osobe virtuelnim odnosima zamenjuju realne odnose (Chak i Leung, 2004; Caplan, 2007) Opisane tendencije vode problematičnoj upotrebi Interneta, koja može rezultirati stvaranjem zavisnosti od Interneta.

Zavisnost od Interneta se opisuje kao oblik bihejvioralne zavisnosti, jer ne podrazumeva unošenje supstance u organizam (Widyanto i McMurran, 2004), zbog čega je najsličnija patološkom kockanju (Young, 1996). Postoje izražene tendencije da se zavisnost od Interneta uvrsti u novu američku klasifikaciju mentalnih oboljenja, DSM-V, pod kategorijom kibernetski poremećaj (Huang i Alessi, 1996, prema Bugarski 2003). Američko udruženje psihijatara predložilo je kriterijume za dijagnostikovanje ovog poremećaja koji obuhvataju: okupiranost Internetom, potrebu za povećanjem vremena provedenog u ovoj aktivnosti da bi se postiglo zadovoljstvo (razvijanje tolerancije), simptome apstinencije (razdražljivost, anksioznost, neraspoloženje...) kada je aktivnost onemogućena, provođenje više vremena u virtuelnim aktivnostima nego što je planirano, neuspele pokušaje redukovanja vremena koje se na Internetu provodi, korišćenje Interneta kao vida bekstva od negativnih osećanja ili problema, zapostavljanje socijalnih, profesionalnih ili porodičnih aktivnosti i dr. (APA, 1994, prema Bugarski 2003).

Pregled istraživanja sa naših prostora ukazuje na postojanje interesovanja domaćih autora za psihološke posledice korišćenja Interneta (npr. Bugarski, 2003), iako tema Virtuelnih socijalnih zajednica nije do sad obrađivana, a istraživanja date teme su retka i u inostranstvu. Zbog toga smo želeli da sprovedemo istraživanje kojim bismo ispitali strukturu i dinamiku ponašanja u VDZ. Takođe, nekonzistentnost rezultata ranijih istraživanja relacija između obrazaca korišćenja Interneta i socijalne anksioznosti upućuje na neophodnost dodatnog istraživanja ove teme, naročito ukoliko postoji mogućnost primene Interneta $\mathrm{u}$ terapijske svrhe.

\section{Metod}

\section{Uzorak}

Istraživanjem je obuhvaćeno 235 ispitanika - korisnika virtuelnih socijalnih zajednica. Po polnoj strukturi uzorak je sačinjavalo 146 žena $(62,1 \%)$ i 86 muškaraca $(36,6 \%)$, dok je prosečna starost ispitanika u uzorku bila oko 25 godina $(\mathrm{AS}=24,78)$, sa rasponom godina od $14-42$. 


\section{Instrumenti i procedura}

U svrhu operacionalizacije ponašanja u virtuelnim društvenim zajednicama konstruisana je skala nazvana Social Networking Behaviour (SNB) sačinjena od 73 stavke sa Likertovom petostepenom skalom za odgovaranje. Manji broj stavki je nastao adaptacijom pojedinih stavki iz Internet Addiction Test-a (IAT; Young, 1999) i skale Zavisnost od interneta (Bugarski \& Lauri Korajlija, 2003) tako da odgovaraju kontekstu VDZ, dok je preostali, veći broj stavki konstruisan namenski za merenje različitih aspekata virtuelnih ponašanja u datom kontekstu.

Socijalna anksioznost operacionalizovana je skraćenom verzijom skale Fear of Negative Evaluation (Leary, 1983) koja se sastoji iz 12 stavki sa Likertovim petostepenim formatom odgovora.

Komplet upitnika distribuiran je ispitanicima na više načina. Najveći broj ispitanika kontaktiran je preko VDZ tako što im je poslata informacija o istraživanju koje se sprovodi, te su zamoljeni da preuzmu upitnik u elektronskom formatu sa datog e-mail naloga, popune ga i pošalju sa istog (anonimnog) naloga autorima istraživanja. Manjem broju ispitanika upitnik je distribuiran u formatu papir-iolovka.

\section{Rezultati}

U cilju opisivanja latentne strukture prostora upitnika SNB sprovedena je analiza glavnih komponenti kojom je ekstrahovano 20 komponenti sa karakterističnim korenovima iznad jedinice, dok je Scree kriterijum (Grafikon 1) sugerisao soluciju sa 8 komponenti.

U ponovljenim analizama sa unapred definisanim brojem faktora (4, 5, 6 i 7) odlučeno je da se, kao najinterpretabilnija, zadrži solucija sa 5 komponenti koja objašnjava 38\% ukupne varijanse (Tabela 1). Komponente su rotirane u Promax poziciju. 
Ponašanje u virtuelnim društvenim zajednicama i socijalna anksioznost

Tabela 1. Glavne komponente upitnika SNB: karakteristični koreni i procenat objašnjene varijanse

\begin{tabular}{lcccc}
\hline Komponenta & \multicolumn{3}{c}{ Nerotirana solucija } & Rotirana solucija \\
\cline { 2 - 5 } & $\begin{array}{c}\text { Karakteristični } \\
\text { koren }\end{array}$ & $\begin{array}{c}\text { \% objašnjene } \\
\text { varijanse }\end{array}$ & $\begin{array}{c}\text { Kumulativni } \\
\%\end{array}$ & $\begin{array}{c}\text { Karakteristični } \\
\text { koren }\end{array}$ \\
\hline 1 & 15.92 & 21.80 & 21.80 & 12.21 \\
2 & 3.62 & 4.96 & 26.76 & 12.33 \\
3 & 3.40 & 4.66 & 31.42 & 10.72 \\
4 & 2.66 & 3.65 & 35.07 & 5.87 \\
5 & 2.21 & 3.03 & 38.09 & 3.25 \\
\hline
\end{tabular}

\section{Scree test}

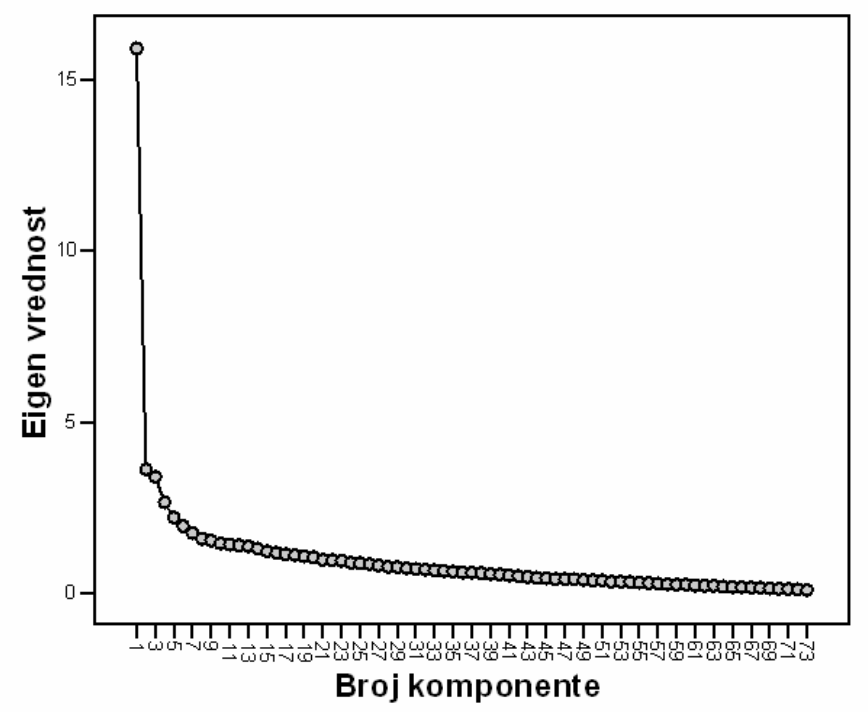

Grafikon 1. Scree dijagram 
Tabela 2. Izvod iz matrice sklopa prve glavne komponente upitnika SNB

Stavka

Uvek se obradujem kada negde uživo sretnem osobu koju znam sa Interneta.

.80

Neke ljude sa kojima komuniciram isključivo preko SNS*-a doživljavam kao $\quad .74$ prave prijatelje.

Za mene je Internet samo još jedan način da upoznam nove i interesantne ljude.

Inicirao sam susret sa osobom koju sam upoznao preko nekog SNS.

Preko Interneta sam upoznao osobu sa kojom sam bio ili sam još uvek u bliskoj vezi.

Nemam želju da upoznam svoje virtuelne prijatelje i uživo.

Volim da flertujem sa osobama preko SNS.

Ljudi koje sam upoznao virtuelno su me bolje prihvatili nego mnogi koje poznajem i privatno.

Sa ljudima koje sam upoznao preko SNS imam više zajedničkih tema nego sa mnogima koje znam iz "realnog života".

Imam jak osećaj zajedništva sa ljudima koje sam upoznao preko SNS.

* skraćenica SNS u čitavom upitniku odnosi se na engleski termin Social Networking Sites ili, na srpskom, Virtuelne društvene zajednice

Sadržaj prve Promax komponente ukazuje na korišćenje VDZ-a za poboljšanje socijalnog života. Osobe koje karakteriše ovakvo ponašanje koriste Internet za pronalaženje novih prijateljstava koja za njih imaju jednak status kao prijateljstva iz „realnog života“, a koja često bivaju prebačena iz on-line u off-line okruženje. Ova latentna dimenzija nazvana je Socijalizacija putem VDZ. 
Tabela 3. Izvod iz matrice sklopa druge glavne komponente upitnika SNB

Stavka

Često se na SNS zadržim duže nego što sam planirao.

Često odlažem neki posao zbog "ćaskanja” ili ostavljanja poruka nekome na SNS.

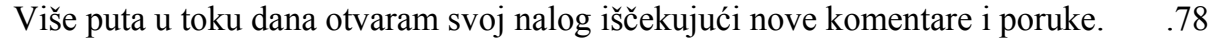

Često mi se dešava da na SNS provedem i više od tri sata u kontinuitetu.

Neki ljudi iz mog ličnog okruženja su mi skrenuli pažnju da previše koristim SNS.

Dešava mi se da zarad dužeg boravka na SNS spavam znatno manje nego uobičajeno.

Mogu bez problema da izdržim i par dana, a da ne proverim da li mi je neko poslao poruku preko SNS.

Više puta sam pokušavao da smanjim vreme provedeno na SNS, ali u tome nisam uspevao.

Kada se osećam usamljenim odlazim na SNS.

SNS mi pomaže da pobegnem od svakodnevnih problema i lošeg raspoloženja.

Ponekad sam toliko zaokupljen aktivnostima na SNS da zaboravim da jedem.

Komunikacija sa drugim ljudima na SNS mi je puno značila u nekim lošim periodima u životu.

Pokušavam da od drugih sakrijem koliko vremena provodim na SNS.

Druga glavna komponenta iz prostora upitnika SNB opisuje ekscesivnu upotrebu VDZ koju odlikuje nemogućnost kontrole vremena provedenog na VDZ, prokrastinaciju drugih obaveza zbog aktivnosti u VDZ. Takođe, u ovu latentnu dimenziju svrstavaju se indikatori koji ukazuju da VDZ za pojedine osobe može imati terapeutsko dejstvo jer ih oslobađa usamljenosti i svakodnevnih briga, pa predstavlja zgodan način bekstva od „surove“ realnosti. Zbog sadržinskog podudara- 
nja sa gore navedenim dijagnostičkim kriterijumima ovisnosti o Internetu komponenta je nazvana Zavisnost od VDZ.

Tabela 4. Izvod iz matrice sklopa treće glavne komponente upitnika SNB

\begin{tabular}{lc}
\hline Stavka & .78 \\
\hline Strepim da bih mogao sresti neke virtuelne prijatelje u realnom životu. & .69 \\
Ostvarivao sam kontakt sa osobama preko SNS zbog seksa. & \\
„Ulepšavao” sam neke informacije o sebi u komunikaciji na SNS da bih osvo- & .62 \\
jio nečije simpatije. & .60 \\
Nisam postavio na profil ni jednu fotografiju na kojoj se ja vidim. & .56 \\
$\begin{array}{l}\text { Kada nisam na Internetu povlačim se u sebe (osećam se depresivnije, bezvolj- } \\
\text { nije). }\end{array}$ & .56 \\
$\begin{array}{l}\text { Bolje se provodim ćaskajući sa ljudima na SNS nego na bilo koji drugi način. } \\
\text { Ljudi mi kažu da sam se promenio od kad koristim SNS. }\end{array}$ \\
$\begin{array}{l}\text { Od kad sam član određene Internet zajednice manje se viđam sa svojim prijate- } \\
\text { lijima. }\end{array}$ \\
$\begin{array}{l}\text { Imao sam loša iskustva sa osobama koje znam sa SNS, a upoznao sam ih i lič- } \\
\text { no. }\end{array}$ \\
$\begin{array}{l}\text { Pre bih proveo popodne i/ili veče na SNS nego to vreme posvetio nekim dru- } \\
\text { gim aktivnostima. }\end{array}$ \\
$\begin{array}{l}\text { Bolje se zabavljam sa ljudima koje znam preko Interneta, nego sa onima koje } \\
\text { lično poznajem. }\end{array}$
\end{tabular}

Treća ekstrahovana komponenta opisuje ponašanje osobe koja doživljava snažno zadovoljstvo kroz korišćenje VDZ-a, a koje proizilazi iz mogućnosti da se, bez posledica u realnom svetu, ,ulepšavaju“ informacije o sebi u virtuelnoj komunikaciji i time ostvari osećaj veće kompetencije ili jačeg samopoštovanja. Međutim, kao posledicu prikrivanja svojih „loših strana“ (na šta ukazuje npr. izbegavanje postavljanja sopstvenih fotografija na profil), osoba ima strah od susreta sa 26 
virtuelnim prijateljima u realnom svetu zbog čega virtuelni i realni život drži na distanci. Ova latentna dimenzija imenovana je Kompenzatorno korišćenje VDZ.

Tabela 5. Izvod iz matrice sklopa četvrte glavne komponente upitnika SNB

\begin{tabular}{lc}
\hline Stavka & .74 \\
\hline Drago mi je kad me neko postavi među najbolje prijatelje (“top friends”). & .73 \\
Veoma vodim računa o tome ko će mi biti među najboljim prijateljima (“top & .58 \\
friends-ima”). & .55 \\
Svoj profil doživljavam kao veoma ličan prostor. & .54 \\
Pažljivo odabiram slike koje ću postaviti na svoj profil. & .49 \\
Na osnovu mojih najboljih prijatelja (,top friends-a") posetioci mog profila & .43 \\
mogu da zaključe dosta i o meni. & \\
Stalno menjam detalje na svom profilu na SNS. & .41 \\
Uživam da drugima ostavljam sličice i druge zabavne stvari preko SNS. \\
$\begin{array}{l}\text { Kada neko otvori moj profil na SNS lako može steći utisak kakva sam ja oso- } \\
\text { ba. }\end{array}$
\end{tabular}

Četvrta ekstrahovana latentna dimenzija opisuje tendenciju ka aktivnom kreiranju virtuelnog profila kao nosioca identiteta osobe na Internetu. Osobe sa visokim skorovima na ovoj dimenziji svoj virtuelni profil doživljavaju kao medijum za prenošenje informacija o sebi (verovatno ponekad nerealnih i idealizovanih) drugim korisnicima, pa je ova dimenzija nazvana Virtuelni self. 
Tabela 6. Izvod iz matrice sklopa pete glavne komponente upitnika SNB

Stavka

Imam osećaj da se ljudi na SNS pretvaraju da su drugačiji nego što jesu. $\quad .70$

Osećam da je komunikacija preko SNS puna stereotipa i pretvaranja. $\quad .69$

Smatram da je komunikacija preko SNS bezlična i sterilna.

Često shvatim kako sa prijateljima sa SNS ustvari nemam ništa zajedničko. $\quad .60$

Brzo me zamara i dosadi mi razmenjivanje poruka sa ljudima preko SNS. $\quad .53$

Većina osoba koje koriste SNS su besposličari. $\quad .51$

Neprijatno mi je da se poveravam nekome sa Interneta, pošto ne mogu da budem siguran u to što znam o njemu.

Nervira me kad mi ljudi sa kojima nemam ništa zajedničko šalju poziv za prijateljstvo.

Poslednja ekstrahovana komponenta govori o Negativnom stavu prema prema VDZ koji proizilazi iz osećaja izveštačenosti i neprirodnosti virtuelne komunikacije, kao i negativnog odnosa prema korisnicima VDZ.

Tabela 7. Interkorelacije Promax komponenti ekstrahovanih iz prostora upitnika SNB

\begin{tabular}{ccccc}
\hline Komponenta & 1 & 2 & 3 & 4 \\
\hline 2 & .55 & & & \\
3 & .54 & .53 & & \\
4 & .31 & .36 & .17 & .00 \\
5 & -.03 & .04 & .10 & \\
\hline
\end{tabular}

Glavne komponente ekstrahovane iz prostora upitnika SNB pokazuju obrazac značajne međusobne povezanosti, osim u slučaju dimenzije Negativan stav prema VDZ koja ne korelira značajno sa ostalim dimenzijama. Dimenzija Kompenzatorno korišćenje VDZ, takođe, nije značajno povezana sa dimenzijom Virtuelni self.

U cilju utvrđivanja relacija latentnih dimenzija skale SNB sa socijalnom anksioznošću sprovedena je regresiona analiza. Za meru socijalne anksioznosti uzeta je prva glavna komponenta ekstrahovana iz prostora skale FNE. 
Regresioni model, u kom je socijalna anksioznost uzeta kao kriterijum, dok su faktorski skorovi ispitanika na dimenzijama skale SNB uzeti za prediktore, je statistički značajan $(\mathrm{R}=.371 ; \mathrm{F}=7.32 ; \mathrm{df}=5 ; \mathrm{p}<.001)$. Prediktorske varijable objašnjavaju oko $12 \%$ varijanse kriterijuma (prilagođeni $\mathrm{R}^{2}=.119$ ). Standardizovani Beta koeficijenti prediktora, vrednosti t-testa i njihova statistička značajnost prikazani su u Tabeli 8.

Tabela 8. Standardizovani Beta koeficijenti prediktora, vrednosti t-testa i njihova statistička značajnost

\begin{tabular}{lccc}
\hline \multicolumn{1}{c}{ Prediktor } & $\begin{array}{c}\text { Standardizovani } \\
\beta \text {-koeficijent }\end{array}$ & $\mathrm{t}$ & $\mathrm{p}$ \\
\hline Socijalizacija putem VDZ & -.04 & -.47 & .64 \\
Zavisnost od VDZ & .25 & 3.12 & .00 \\
Kompenzatorno korišćenje & .14 & 1.73 & .09 \\
VDZ & .10 & 1.56 & .12 \\
Virtuelni self & .04 & .59 & .56 \\
Negativan stav prema VDZ & & & \\
\hline
\end{tabular}

\section{Diskusija}

Cilj ovog istraživanja bio je utvrditi latentnu strukturu ponašanja u Virtuelnim društvenim zajednicama, kao i relacije tih latentnih dimenzija sa socijalnom anksioznošću.

Rezultati pokazuju da se virtuelno ponašanje ispoljava višedimenzionalno. Analizom glavnih komponenti utvrđeno je postojanje pet dimenzija ponašanja: Socijalizacija putem VDZ, Zavisnost od VDZ, Kompenzatorno korišćenje VDZ, Virtuelni self i Negativan stav prema VDZ.

Dimenzija Socijalizacija putem VDZ govori o doživljaju ovih servisa kao samo još jednog načina da se steknu nova prijateljstva, koja lako iz virtuelnog prelaze u realno okruženje. Privlačnost ovog načina povezivanja dolazi iz mogućnosti da se a priori pronađu prijatelji sa sličnim interesovanjima ("Sa ljudima koje sam upoznao preko SNS imam više zajedničkih tema nego sa mnogima koje znam iz "realnog života"). Sadržaj dimenzije Zavisnost od VDZ ukazuje na niz disfunkcionalnih obrazaca korišćenja ovih servisa: veliki broj sati utrošen na njima i 
neuspešne pokušaje da se to kontroliše, prokrastinaciju drugih obaveza i deprivacija sna zbog aktivnosti na njima, kao i bežanje od problema i osećaja usamljenosti. Upravo ova ponašanja predstavljaju kriterijume za dijagnostikovanje ovisnosti o Internetu (Huang, 1996, prema Bugarski, 2003), odnosno u ovom slučaju specifičnog tipa ovisnosti ponekad nazvanog "Cyber-relationship addiction" (Young, 1999, prema Bugarski, 2003; Grohol, (n.d.), prema Bugarski, 2003). Dimenzija Kompenzatorno korišćenje VDZ ispoljava se kroz manipulisanje informacijama u komunikaciji i predstavljanju na VDZ. Komunikacija putem Internet oslobađa učesnike od odgovornosti i posledica u realnom svetu sve dok se ne sretnu u realnosti. Iz tog razloga ona može postati veoma privlačna osobama koje iz bilo kog razloga osećaju strah od neprihvatanja u neposrednoj komunikaciji, bilo da su u pitanju nepoželjne fizičke karakteristike ili neke druge nekompetencije osobe (Zhao, Grasmuck \& Martin, 2008; Bargh \& McKenna, 2004). Zbog toga ovakva komunikacija može biti izvor velikog zadovoljstva ("Od kad koristim SNS zadovoljniji sam sobom") i postati zamena za prijateljstva iz realnog sveta ("Od kad sam član određene Internet zajednice manje se viđam sa svojim prijateljima."), odnosno dovesti do povlačenja kada osobi nije dostupna ("Kada nisam na Internetu povlačim se u sebe (osećam se depresivnije, bezvoljnije)"). Virtuelni self opisuje doživljaj virtuelnog profila kao sastavnog dela self-koncepta ("Svoj profil doživljavam kao veoma ličan prostor”) preko kog se drugima može jasno izraziti lični identitet ("Kada neko otvori moj profil na SNS lako može steći utisak kakva sam ja osoba.”). Mogućnost aktivnog kreiranja virtuelnog identiteta osobi omogućava ispoljavanje "Realnog ja" - onog aspekta sopstvene ličnosti za koji ona veruje da je neispoljen i neprepoznat od strane drugih (McKenna, Green \& Gleason, 2002, Study 1), ili eksperimentisanje sa različitim socijalnim identitetima. Konačno, dimenzija Negativan stav prema VDZ ukazuje da postoje pojedinci koji, uprkos tome što su i sami korisnici ovih servisa, imaju negativan stav prema njima. Moglo bi se pretpostaviti da su to pojedinci koji su se zasitili ove vrste komunikacije ("Brzo me zamara i dosadi mi razmenjivanje poruka sa ljudima preko SNS."), bili svedoci toga da ljudi oko njih ekscesivno koriste VDZ (Većina osoba koje koriste SNS su besposličari."), a možda čak i sami ranije bili zavisnici od VDZ. Ova dimenzija je nezavisna od ostalih dimenzija virtuelnog ponašanja na VDZ.

Prve tri ekstrahovane dimenzije virtuelnog ponašanja na VDZ pokazuju obrazac srednje visoke povezanosti. To ukazuje da osobe koje preferiraju VDZ kao sredstvo povezivanja sa ljudima i poboljšanje socijalnog života, često ne uspevaju da kontrolišu vreme provedeno u ovim aktivnostima. Kod osoba koje intenzivno koriste VDZ za druženje, ali isključivo u virtuelnom domenu, ovakva komunikacija može biti način da se prevaziđe osećaj nekompetentnosti. McKenna et al (2002) ističu da manje fizički privlačne ili socijalno kompetentne osobe uz po30 
moć Interneta mogu da razviju prijateljstvo do stadijuma u kom može doći do razotkrivanja intimnih informacija, što je u realnosti često onemogućeno jer ove nekompetencije, utičući na prvu (nepovoljnu) impresiju o osobi, sprečavaju razvoj odnosa dalje od početne tačke.

Tendencija ekspresije identiteta preko virtuelnog profila izraženija je kod osoba koje u većoj meri koriste VDZ za uspostavljanje novih prijateljstava i kod kojih njihovo korišćenje dostiže nivo zavisnosti.

Konačno, istraživanje je pokazalo da je socijalna anksioznost značajno povezana samo sa ovisničkim korišćenjem VDZ, mada možemo govoriti i o tendenciji povezanosti sa dimenzijom Kompenzatorno korišćenje VDZ $(\mathrm{p}<.10)$. Navedeni nalazi sugerišu da socijalno anksiozni ove servise delimično koriste i u cilju prevazilaženja problema i osećaja usamljenosti. Slični zaključci o mogućem terapijskom dejstvu korišćenja Interneta, izvedeni su i iz nekoliko ranijih studija (McKenna et al, 2002; Campbell et al, 2006). Sa druge strane, rezultati dobijeni ovim istraživanjem ipak upozoravaju da potencijalna "terapija" može proizvesti neželjene efekte izazivajući novi problem - zavisnost od Interneta, čime podržavaju nalaze druge grupe istraživanja (Nie \& Erbung, 2000, prema Bargh \& McKenna, 2004; Kraut et al, 1998, prema Bargh \& McKenna, 2004). Potencijalni problem se javlja i u pogledu toga što socijalno anksiozni mogu ispoljiti tendenciju da virtuelnom komunikacijom i prijateljstvima zamene realne i time, umesto da rade na problemu unapređivanja interpersonalnih veština, samo ga odlože. Sličnu tendenciju opisuju i King i Poulos (1998, prema Campbell et al, 2006), čime ukazuju na potencijalne probleme korišćenja kompjuterski posredovane komunikacije u lečenju socijalne fobije i generalizovanog anksioznog poremećaja.

Konačno, možemo zaključiti da rezultati ovog istraživanja idu u prilog teoriji socijalne kompenzacije (Jochen et al, 2005) po kojoj kompjuterski posredovana komunikacija privlači socijalno anksiozne osobe omogućujući im da kompenzuju probleme u socijalnom funkcionisanju. Ipak, ova teorija ima samo ograničenu eksplanatornu moć u pogledu objašnjenja privlačnosti VDZ, jer ne omogućava izvođenje zaključka o tome šta privlači njihove mnogobrojne korisnike koji ne ispoljavaju kompenzatorno korišćenje ovih servisa koje je samo jedan od obrazaca virtuelnih ponašanja $\mathrm{u}$ VDZ. 


\section{Zaključak}

Fenomen Virtuelnih društvenih zajednica predstavlja novu vrstu opsesije informatičkog društva, naročito mladih ljudi. Međutim, kao i po pitanju drugih fenomena vezanih za Internet, impresije vezane za njih variraju od zabrinutosti do oduševljenja.

Sprovedeno istraživanje pokazalo je da je virtuelni svet u izvesnoj meri preslikani realni svet $u$ kom postoje različiti vidovi ponašanja i dinamika slična realnoj: sklapanje prijateljstava, druženje i komunikacija, izgrađivanje ličnog identiteta, samoprezentacija, ali i strahovi i strepnje i nastojanja da se sopstveni problemi reše ili da se od njih pobegne.

Međutim, anonimnost, minimalna kontrola i neregulisanost ponašanja uobičajenim socijalnim normama realnog sveta omogućile su komunikaciju i ponašanje oslobođeno od posledica, kao i mogućnost eksperimentisanja sa različitim identitetima. Ove odlike virtuelnog sveta učinile su virtuelnu komunikaciju veoma privlačnom, dok su za mnoge psihologe postale potencijalni kapacitet za prevazilaženje raznih problema življenja: socijalne anksioznosti, usamljenosti i drugih socijalno uslovljenih problema.

Međutim, ove odlike kompjuterski posredovane komunikacije donele su i fenomen koji je izazvao najveću zabrinutost kada je u pitanju Internet - zavisnost od Interneta, odnosno specifičnu vrstu ove zavisnosti - zavisnost od virtuelnih odnosa (Cyber-relationship addiction). Rezultati našeg istraživanja ne spore mogućnost kompenzacije problema življenja putem efekata korišćenja Interneta i Virtuelnih društvenih zajednica, ali stavljaju ozbiljno ograničenje na mogućnost korišćenja ovih servisa u terapiji socijalne anksioznosti koje proističe iz opasnosti stvaranja zavisnosti od ovakvih servisa.

$\mathrm{Na}$ kraju, potrebno je dati nekoliko smernica za dalja istraživanja date teme. S obzirom da se u literaturi mogu naći različita shvatanja o potrebnom broju ispitanika u odnosu na broj stavki u faktorskoj analizi (Garson, n.d.), bilo bi poželjno sprovesti analizu glavnih komponenti upitnika SNB na većem uzorku. Osim toga, u ovom istraživanju relacije između socijalne anksioznosti i dimenzija ponašanja na VDZ ispitivane su u transferzalnom istraživačkom nacrtu. Longitudinalna istraživanja ove povezanosti bi bila više nego dobrodošla, kao i pažljivo ispitivanje efekata eventualnih pokušaja tretmana socijalne anksioznosti uz podršku ili posredstvom VDZ. Konačno, smatramo da bi relacije između ponašanja na VDZ i socijalne anksioznosti u budućnosti trebalo razmatrati u širem kontekstu sociodemografskih karakteristika korisnika, kao i drugih parametara "online" ponašanja. 


\section{Reference}

Antonijević, S. (1999). Virtuelne zajednice i društveni odnosi na Internetu. Retrieved October 18, 2008

from:http:/www.komunikacija.org.yu/komunikacija/casopisi/sociologija/X LI_2/d006/show_html?stdlang=ser_cyrB92. (2008). U trendu je imati profil na Facebooku. Retrieved October 20, 2008 from: http:/www.b92.net/zivot/vesti.php?nav_id=318961

Bargh, J. \& McKenna, K. (2004). The Internet and social life. Annual review of psychology, 55, 573-590.

Bugarski, V. (2003). Zavisnost od Interneta - na putu ka novoj dijagnostičkoj kategoriji. Aktuelnosti iz neurologije, psihijatrije i graničnih područja, 2, $50-56$.

Bugarski, V. \& Lauri Korajlija, A. (2003). Zloupotreba interneta ili put k novoj dijagnostičkoj kategoriji. Saopštenje na skupu XVI Dani Ramira Bujasa, Zagreb, knjiga rezimea, str. 23.

Campell, A. J., Cumming, S. R. \& Hughes, I. (2008). Internet use by socially fearful: Addiction or therapy? CyberPsihology \& Behavior, 9, 69-81.

Caplan, S. (2007). Relations among loneliness, social anxiety and problematic Internet use. CyberPsychology \& Behavior, 10, 234- 242.

Chak, K. \& Leung, L. (2004). Shyness and locus of control as predictors of Internet addiction and Internet use. CyberPsihology and Behavior, 7, 559- 570.

Facebook press. (n.d.). Retrieved July 20, 2008 from: http://www.facebook.com

Garson, G. D. (n.d.). Factor Analysis. Statnotes: Topics in Multivariate Analysis. Retrieved November 5, 2008 from:

http://www2.chass.ncsu.edu/garson/pa765/statnote.htm.

Gross, E., Juvonen, J. \& Gable S. (2002). Internet use and well-being in adolescence. Journal of social issues, 58, 70-99.

Jochen, P., Valkenburg, P. M. \& Schouten, A. P. (2005). Developing a model of adolescent friendship formation on the Internet. CyberPsychology and Behavior, 8, 423-430.

Leary, M.R. (1983). A brief version of the Fear of Negative Evaluation Scale. Personality \& Social Psychology Bulletin, 9, 371-375. 
McKenna, K. Y. A., Green, A. S. \& Gleason, M. E. J. (2002). Relationship Formation on the Internet: What's the Big Attraction? Journal of Social Issues, 58, 9-31.

Petrović, M. (n.d.). Internet kao mesto susreta: odnosi na mreži. Retrieved April 18, 2008 from: http://www.bos.org.yu/cepit/evolucija/html/11/odnosi.htm

Phillips, L., Rochau, M., Wobido, N. J., Mastilo, T., Pent, K. \& Chapman, M. (2006). OurSpace: An Investigation into the Mediated Social Networks of Danish Teenagers. Retrieved August 21, 2008 from: http://www.diggy.ruc.dk/bitstream /1800/2088/1/ whole\%20thing-\%20last.pdf

Scealy, M., Phillips, J. \& Stevenson, R. (2002). Shyness and anxiety as predictors of patterns of Internet usage. CyberPsihology \& Behavior, 5, 507- 515

Suler, J. (2003). The psychology of cyberspace. Retrieved October 20, 2008 from: www.rider.edu/suler/psycyber/psycyber.html

Widyanto, L. \& McMurran, M. (2004). The psychometric properties of the Internet addiction test. CyberPsychology \& Behavior, 7, 443-450.

Young, K. (1996). Internet addiction: The emergence of a new disorder. CyberPsychology \& Behavior, 1, 237-244.

Young, K. (1999). Internet Addiction Test (IAD). Retreived October 20, 2008 from: http://www.netaddiction.com/resources/Internet_addiction_test.htm

Zhao, S., Grasmuck, S. \& Martin, J.(2008). Identity construction on Facebook: Digital empowerment in anchored relationships. Computers in Human Behaviour, 24, 1816-1836. 


\title{
ABSTRACT
}

\section{LATENT STRUCTURE OF BEHAVIOUR ON SOCIAL NETWORKING SITES AND ITS RELATION TO SOCIAL AXIETY}

\author{
Bojana Bodroža, Sandra Jovanović \& Boris Popov
}

Social Networking Sites (SNS) representing a virtual space for communication and development of social relations attract more and more users. The Social Compensation Theory, intending to explain this form of communication, suggests that socally anxious, introverted and diffident persons can find SNS communication particularly interesting in order to compensate for their lack of faceto-face interpersonal skills.

This study was conducted with the following goals: 1) to explore and describe the latent strucure of behavior on SNS, and 2) to explore relations between such behavior and social anxiety. In order to operationalize SNS behavior, the Social Networking Behaviour scale (SNB), a 73-item scale, was created.

Using a principal component analysis with Promax rotation, five interpretable factors of virtual behavior were extracted: 1) Socializing through SNS, 2) SNS addiction, 3) Compensatory use of SNS, 4) Virtual self and 5) Negative attitude towards SNS. All factors were significantly correlated, excepting Negative attitude towards SNS. Regression analyses suggested that Social anxiety was significantly related only to SNS addiction and marginally related to Compensatory use of SNS.

Although the results of this study provide partial support to some previous studies showing that internet communication services can have positive therapeutic impact on people with interpersonal problems, they also point to the potential risks. Namely, using SNS in treatment of social anxiety may have harmful effects, resulting in SNS addiction.

Key words: cyber behaviour, social networking sites, social anxiety, internet 